\title{
Az egységes mértékegységrendszer kialakítása, fenntartása és továbbfejlesztése
}

\author{
Ádám József
}

DOI: https://doi.org/10.30921/GK.71.2019.3.1

Absztrakt: A tanulmány az egységes mértékegységrendszer kialakitásával, fenntartásával és legutóbbi továbbfejlesztésével, valamint a hazai bevezetésével foglalkozik. Az egységes mértékrendszert „minden idökre - minden népnek” szándékával alkották meg. Kezdettôl fogva törekedtek arra, hogy önkényes referencia helyett, nemzetközileg elfogadott „természeti állandók” alapul vételével hosszú idôre stabilitást biztosítsanak a mértékegységek fogalmi meghatározásában. 1960-ban a mértékegységek nemzetközi rendszerében (SI) egyeztek meg és fogadták el az SI-t, amelyet ettôl az idôponttól kezdve számos alkalommal felülvizsgáltak. Az SI hét kiválasztott alapegységen (méter, kilogramm, másodperc, amper, kelvin, mól és kandela) és a hozzájuk kapcsolódó alapmennyiségen (hossz, tömeg, idő, elektromos áramerôsség, abszolút hômérséklet, anyagmennyiség és fényerốsség) alapul. A legutóbb felülvizsgált SI valamennyi alapegységének meghatározása fizikai/müszaki állandóhoz kapcsolódik, amely a mértékegységek stabilitását és egyetemességét (univerzalitását) garantálja. A kilogramm az utolsó mértékegység, amelyet eddig a kilogrammetalon alapul vételével határoztak meg fogalmilag, azonban 2019. május 20-tól (a Metrológia Világnapjától) a fogalmi meghatározását (definiálását) már a Planck-féle állandó alapul vételével adják meg.

Abstract: The paper deals with the development, maintenance and latest improvement of the unified standardized units and their domestic introduction in Hungary. The unified metric system was envisioned to be "for all people for all time". From its outset is sought to ensure long-term stability by defining the units in terms of an internationally agreed „constants of nature” instead of an arbitrary reference. In 1960 an International System of units (SI) was agreed and adopted and since that time it has been revised on a number of occasions. The SI is based on the seven base units (metre, kilogram, second, ampere, kelvin, mole and candele) and their corresponding base quantities (length, mass, time, electric current, thermodynamic temperature, amount of substance and luminous intensity). The definitions of all the units of the revised SI are linked to physical constants, which guarantee their stability and universality. The kilogram, the last unit to be defined from an artefact, will henceforth be linked to the Planck constant from May 20th, 2019 (World Metrology Day).

Kulcsszavak: alapegységek, kilogramm, másodperc, méter, méterrendszer, Méteregyezmény, Mértékegységek Nemzetközi Rendszere (SI)

Keywords: base units, kilogram, metre, metre system,

Metre Convention, International System of Units (SI), second

\section{Bevezetés}

Közismert, hogy a geodézia területén alapvető szerepe van a mérésnek. Ehhez a geodéziában is mértékegységre és mérôeszközökre van szükség. Az idôk folyamán sokféle mértékegységet használtak, de a gyakorlati célszerúség és szükségszerúség egységes mértékegységrendszer kialakulásához vezetett.

A tudományok és a múszaki, társadalmi gyakorlat rohamos fejlôdése és növekvố igénye a mérés területén, valamint a mértékegységek fogalomkörében is érezteti hatását. Egyre pontosabb mérésre, ennek következményeként az alapegységek szabatosabb meghatározására és a vonatkozó szakirodalom nemzetközi jellegére tekintettel, egységes jelölésekre van szükség.

\section{A méterrendszer bevezetése}

\subsection{A méterrendszer} bevezetésének kezdete

$\mathrm{Az}$ egységes mértékegységrendszer kidolgozásának kezdete a francia forradalom idôszakára nyúlik vissza. A francia nemzetgyúlés az 1791. március 26-án kiadott dekrétumával létrehozta a mértékek és súlyok általános bizottságát (Commission Générale des Poids et Mesures), az ún. méterbizottságot. Ezt azzal a feladattal bízta meg, hogy a mértékegységek területén uralkodó nagyfokú különbözôségeket szüntesse meg, és alkosson egységes mértékrendszert. A bizottság tagjai (J. C. Borda, M. de Condorcet, J. L. Lagrange, P. S. Laplace és G. Monge) úgy határoztak, hogy az alapvetô hosszegységet a természetbôl választják oly módon, hogy az a Föld meridiánja negyed részének (meridiánkvadránsának) a tízmilliomod része legyen. Ehhez meg kellett határozni a Földünket képviselô ellipszoidi földalak méreteit a lehetô legpontosabban.

Az ún. méterfokmérést (amelyre megbízást $P$. Méchain és J. B. J. Delambre kapott) a párizsi meridiánon mérték a belga határ közelében fekvố Dunkerque-tôl a spanyolországi Barcelona mellett fekvố Montjouy-ig (1.ábra) 1792-1798 között. A Delambre által 1799-ben (220 éve) közölt számítások szerint a Földet képviselố forgási ellipszoidalak meridiánjának az Északisark és az Egyenlítô közé esố ívhossza (meridiánkvadránsa) 5130740 toise lett $(1$ toise $=1,949036 \mathrm{~m})$. Ennek tízmilliomod része 443,295936 párizsi vonal, amelyet felfelé kerekítettek, és így 1 méter $=443,296$ párizsi vonal 


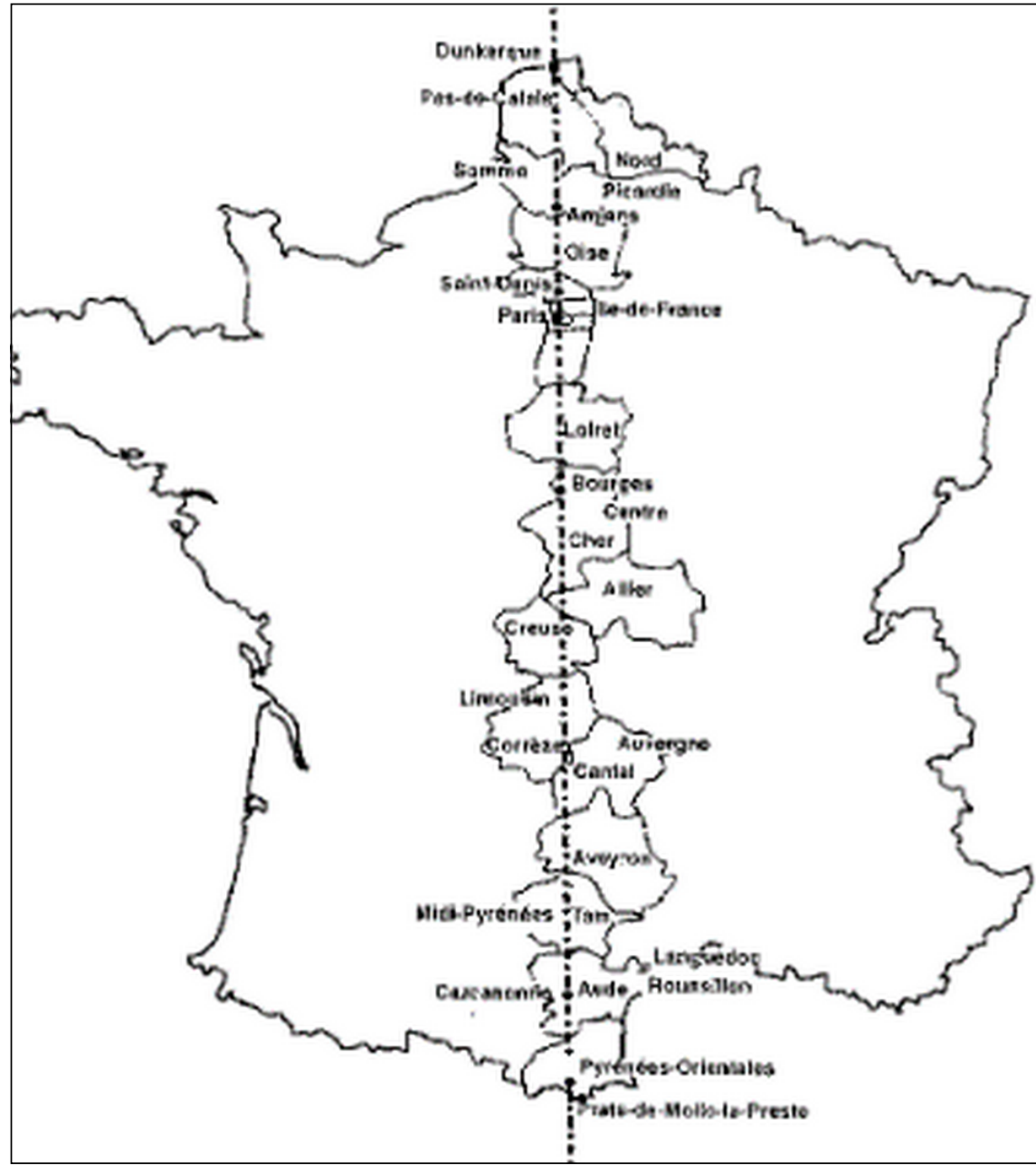

1. ábra. A párizsi meridián méterfokmérést érintố ivdarabja

lett. A méterre ilyen módon kapott hosszúságot egy platinarúdon, annak homloklapjai között jelölték ki (két finom karcolással), s ez a hossz lett a méter. Ezt az etalont a párizsi levéltárban (Köztársasági Archívum) helyezték el, s ezért ezt az etalont „levéltári méter"-nek (Mètre des Archives) nevezik (Rédey 1960). Az új mértékegységet J. C. Borda nevezte el méternek a görög metron szó alapján (Regốczi 1959). A méterbizottság által elfogadott méter tekinthetố a hosszúság elsó, tudományosan meghatározott alapegységének. [Megjegyezzük, hogy a méterfokmérés alapján Földünk ellipszoidi alakjának geometriai jellemzóire Delambre a következó adatokat kapta: a fél nagytengelyhosszra $\mathrm{a}=6375738,7 \mathrm{~m}$ és a geometriai lapultságra f = 1/334,29; (Biró et al. 2013)]

Fontos lépés volt még az, hogy a francia akadémia a méter többszöröseire és törtrészeire a tízes számrendszert vezette be.
A tömeg alapmértékéül a francia nemzetgyúlés azt határozta el (1795), hogy legyen az egysége a méter század része által meghatározott méretû kocka térfogatában elhelyezhetố víz mennyisége a fagyásponton. Ezt a mértéket (gramm) azonban nem lehetett kelló stabilitással elóállítani a kereskedelem számára. Ezért az elsôként megfogalmazott egységnek az ezerszeresét határozták meg, amely a kilogramm lett. Egy kilogramm annyi víznek a tömege, mely egytized méter élhosszúságú kockába fér a víz fagyáspontján. Közben a francia fizikusok mérések alapján megállapították, hogy van a víznek egy még stabilabb pontja: $+4^{\circ} \mathrm{C}$ (amelyet késóbb pontosítottak: $+3,984^{\circ} \mathrm{C}$ ), amelyen maximális a sûrúsége. Ennek alapján készült el platinából a „levéltári kilogramm” (Kilogramm des Archives) 1799-ben (220 éve). Ennek értelmében a kilogramm egy köbdeciméter víz tömege a legnagyobb sûrúségú állapotban $3,984^{\circ} \mathrm{C}$-on és normál légköri nyomáson. Ezáltal a tömeg

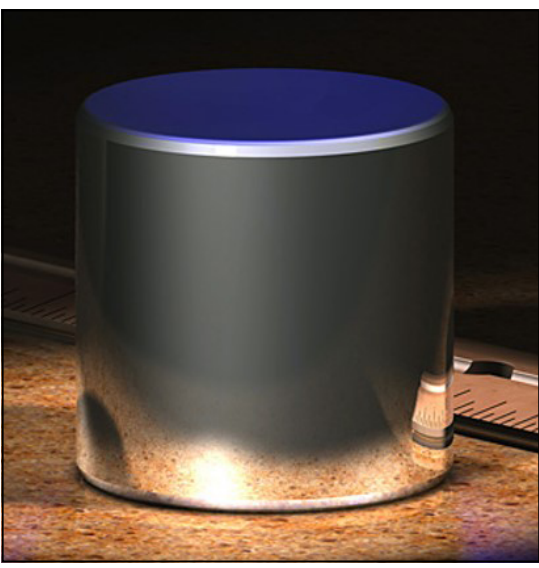

2. ábra. A kilogrammetalon látképe

mértékegysége a köbdeciméter közvetítésével a méterhez, ezen keresztül pedig szintén a Földünk méreteihez kapcsolódik. Itt jegyezzük meg, hogy a kilogrammot 1889 óta platina-irídium ötvözetből készült 39,17 mm átmérôjú és magasságú henger tömegeként határozták meg (definiálták) 2019. május 20-ig (2. ábra).

\subsection{Nagy Károly csillagász szerepe}

Magyarországon Nagy Károly (17971868) csillagász, a bicskei csillagvizsgáló tulajdonosa, az MTA tagja (levelezô tag: 1832 és rendes tag: 1836) volt az, aki az elsók között szorgalmazta a méterrendszer magyarországi bevezetését. Már 1839-ben rámutatott a középkori eredetû mértékrendszerünk nehézkességére. Mivel francia kapcsolatai révén jól ismerte a mértékegységek tízes számrendszerú (decimális) rendszerét, és ennek hasznosságát is világosan látta, így Magyarországra Párizsból ô hozta az elsô (egy párizsi aranymúves által platinából készített) méter- és kilogrammetalont 1844-ben. Ezeket a bicskei gyújteményéból a szabadságharc idején elhurcolták, késôbb visszakerültek, és az MTA ôrizetében és tulajdonában maradtak 1870-ig. 1870-ben az illetékes minisztérium kérésére az MTA - Nagy Károly eredeti szándékának megfelelően - ellenszolgáltatás nélkül átengedte az államnak. A szabadságharc viszontagságai után külföldre ment (Párizsba), s ott élt haláláig; a csillagvizsgálóját, múszereit és könyvtárát az államnak ajándékozta. Értékes gyưjteményeit egyetemek, az MTA, az Erdélyi Múzeum és néhány iskola között osztották szét (Markó et al. 2003). 
Emlékének megórzése céljából, életének és munkásságának kutatására, ápolására 2007-ben megalakult a Nagy Károly Csillagászati Közhasznú Alapítvány.

\subsection{Az egységes mértékek hazai bevezetése}

Magyarországon szervezetszerúen először az 1850-ben alakult Pest-Budai Kereskedelmi és Iparkamara emelt szót a nyugaton már használatos tízes számrendszerú (decimális) mértékrendszer átvétele érdekében. Az első lépést alig több mint 150 évvel ezelôtt a földmúvelésügyi, ipari és kereskedelmi miniszter (Gorove István) tette meg, amikor 1867 júliusában felkérte a Magyar Tudományos Akadémiát (MTA), az Országos Magyar Gazdasági Egyesületet, valamennyi kereskedelmi és iparkamarát, valamint néhány kiválasztott szakértőt, hogy készítsenek javaslatot a méterrendszer bevezetése tárgyában.

Az MTA keretében az akkori III. Osztály vezetôje (osztálytitkára), Szabó József akadémikus intézkedése alapján bizottságot hoztak létre, melynek tagjai (zárójelben a tudományterületük): Kruspér István (geodézia), Nendtvich Károly (kémia), Szily Kálmán (fizika) és Schenzl Guido (geofizika) akadémikus voltak.

A bizottság azt javasolta, hogy a) a tízes számrendszerú (decimális) mértékrendszer legyen általános és kivétel nélküli, b) a mértékegységek nevét nem kell magyarra fordítani, maradjon azok neve méter és kilogramm,c) a szabványos alapmérték a Nagy Károlyféle, platinából készült méter- és

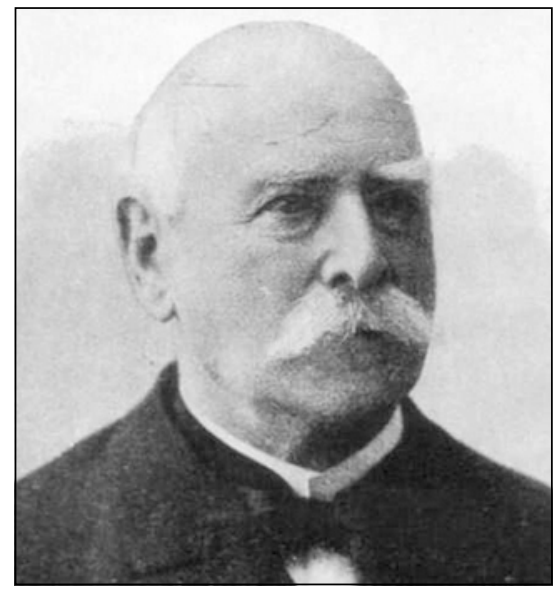

3. ábra. Kruspér István akadémikus arcképe kilogrammetalon legyen, továbbá a bizottság az alapegységeknek a tudományos életben akkor még alig használatos többszöröseit és törtrészeit feleslegesnek nyilvánította (Verố 1970).

A javaslattételre felkért valamenynyi testület és szakértô véleményének alapján az illetékes minisztérium elkezdte a tízes számrendszerú (decimális) mértékek bevezetését szolgáló törvény elôkészítését és megfogalmazását, amelynek során főként az akadémiai bizottság javaslatára támaszkodtak. Közben a minisztérium azzal a kéréssel fordult az MTA felé (1869. december 29-én), hogy a Nagy Károlyféle két etalont az államnak engedje át, és jelölje ki azt a szakembert, aki a párizsi ôsetalonokkal (Mètre et Kilogramme des Archives) az összehasonlítást elvégzi. Az MTA az 1870. január 31-én hozott határozatában „a két etalont, az ajándékozó eredeti szándéka szerint, az államnak átengedi”, továbbá a megfelelô összehasonlítás elvégzésére Szily Kálmánt ajánlotta. A Múegyetem, hasonló felkérésre, Kruspér Istvánt javasolta.

Megfelelố előkészületek után a minisztérium Kruspér István (3. ábra) és Szily Kálmán (4.ábra) akadémikust bízta meg, akik 1870 áprilisában francia szakértő bizottság közremúködésével Párizsban elvégezték a Nagy Károlyféle méter-és kilogrammetalonnak az összehasonlító méréseit a francia levéltárban ôrzött ôsetalonokkal. Az összehasonlító mérések eredményének birtokában törvényjavaslat készült, amelyet (némi huzavona után) végül is 1874. április 20-án (145 éve) VIII. törvénycikk jelzéssel törvényerôre

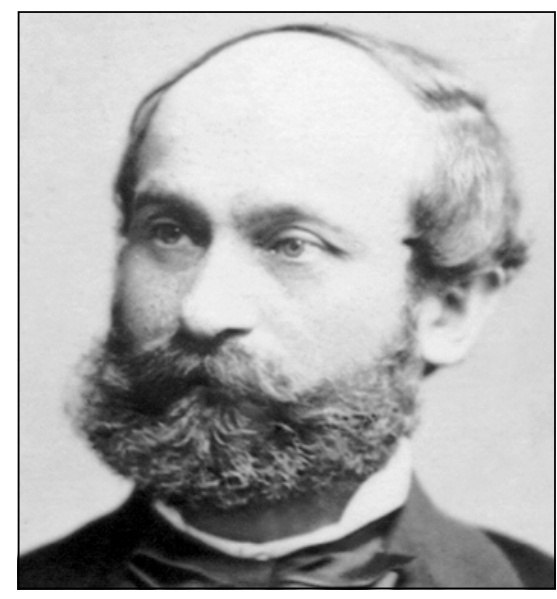

4. ábra. Szily Kálmán akadémikus arcképe emeltek. Ettôl az idốponttól kezdve (a nemzetközi méteregyezmény aláírása elôtt már egy évvel) Magyarországon a méter és a kilogramm az egyedül és kizárólagosan törvényes mértékegységek lettek.

\subsection{Nemzetközi méterértekezlet}

A francia nemzetgyúlés által létrehozott méterbizottság Franciaországban egységesen rendezte a hosszmérés egységét. Európa többi államaiban azonban ugyanakkor nagy eltérések mutatkoztak a hosszmértékek terén. A zavaró állapot megváltoztatása érdekében 1870-ben a francia kormány felkérte az érdekelt országokat, hogy a méterügyben jártas szakembereikkel képviseltessék magukat a Párizsban tartandó nemzetközi tanácskozáson, amely 1874-ig többször összeült. A munkaértekezlet célja lényegében az volt, hogy a méter általános elfogadását ajánlja minden államnak, továbbá javaslatot kellett tennie egy nemzetközi szervezet létrehozására, mely a méterrendszer világméretû elterjesztését intézhetné. Magyarország küldöttei az MTA javaslatára és az illetékes minisztérium megbízása alapján végig Kruspér István és Szily Kálmán akadémikus voltak.

Kruspér István és Szily Kálmán 1870 augusztusának elején ismét Párizsban voltak, mivel a nemzetközi méterértekezlet elsố ülésszaka augusztus 8-án kezdôdött el. Az értekezlet feladata a méter és a kilogramm alapegységek pontos meghatározásának (definíciójának) végérvényesnek szánt megállapítása volt. Az értekezlet munkája azonban a francia-porosz háború kitörése miatt félbeszakadt, ezért a kitűzött feladatának csak a felét tudta megoldani, nevezetesen csak a méterrel foglalkoztak, és ennek ügyében hoztak határozatot. Mivel a XIX. század első két harmadában végzett fokmérések a 2. 1.-ben ismertetett „méterfokméréstôl” eltérô eredményeket szolgáltattak, ezért az értekezlet azt a határozatot hozta, hogy a méter maradjon egyenlố a „levéltári méter" (Mètre des Archives) hosszával, azaz a levéltári méter legyen a méter alapegységének egyetlen hiteles megtestesítôje, és lényegében az is maradt 1889-ig, amikor az új nemzetközi méterprototípus kijelölésére sor kerülhetett (Verố 1970). 
Az 1870 augusztusában félbeszakadt méterértekezlet 1872-ben folytatódott, amelyen már 29 ország képviseltette magát. Ezen foglalkoztak a kilogrammalapmérték pontos meghatározásával, az említett nemzetközi szervezet létrehozására vonatkozó javaslattal, és olyan tervet készítettek, amelynek végrehajtásával az érdekelt országok hiteles méter- és kilogrammetalonok birtokába juthatnának. Erre először 1874-ben tettek kísérletet, azonban a párizsi Conservatoire des Arts et Métiers múhelyében készített $27 \mathrm{db}$ méterrúd és $40 \mathrm{db}$ kilogrammetalon elkészítése sikertelenné vált. Mivel alapvetó kívánalom volt az, hogy a méter és a kilogramm valamenynyi országban pontosan ugyanakkora legyen, ezért az újabb méter- és kilogrammetalonok elkészíttetésére 1882ig kellett várni.

Itt jegyezzük meg azt, hogy Kruspér István az 1870. augusztusi méterértekezletrôl és a korábbi, kapcsolódó tudományos tevékenységérôl az 1871. február 13-án tartott akadémiai székfoglaló elôadásában számolt be (Kruspér 1871). A Nagy Károly-féle etalonok párizsi ellenőrzése és a méterértekezlet keretében kifejtett kiváló szakmai munkájának elismeréséül szép, tengerkék, aranyozott sévres-i porcelánváza ôrzi nevét és a párizsi értekezlet emlékét, 1872-es évszámmal, amelyet családja a Magyar Nemzeti Múzeumnak ajándékozott.

A méterértekezlet kitartó tevékenysége odavezetett, hogy 1875 . május 20-án a francia kormány meghívása és szervezése alapján 17 állam diplomáciai képviselôje Párizsban aláírta a Méteregyezmény (Convention du Mètre) néven ismertté vált nemzetközi egyezményt, amelyet az OsztrákMagyar Monarchia képviseletében Apponyi Rudolf párizsi nagykövet írt alá. Mivel aláírása két ország csatlakozását jelentette az egyezményhez, így a 18, többségében európai ország azt a kötelezettséget vállalta, hogy a francia forradalom éveiben született tízes számrendszerú (decimális) mértékegységek rendszerét bevezeti. Magyarország az egyezményben vállalt kötelezettségeit az 1876. évi II. törvénycikként iktatta a törvényei közé.

\subsection{A Nemzetközi méteregyezmény intézményei és múködésük}

A nemzetközi méteregyezmény (Convention du Mètre) a méterrendszer elterjesztésének intézésére három szerv életre hívását határozta el (a párizsi méterértekezlet ajánlása értelmében):

1. Általános Súly- és Mértékügyi Konferencia (Conférence Générale des Poids et Mesures, CGPM), mely általában négyévente ülésezik. A CGPM résztvevôi az országuk kormányát képviselik, és minden résztvevố országra kötelezô határozatokat hoz;

2. Nemzetközi Súly-és Mértékügyi Bizottság (Comité Internationale des Poids et Mesures, CIPM), amelynek jelenleg 18 különbözô állampolgárságú tudós tagja van. Fontos feladata a CGPM határozatainak előkészítése.

3. Nemzetközi Súly-és Mértékügyi Hivatal (Bureau Internationale des Poids et Mesures, BIPM), amely a méterrendszerú országokkal állandó kapcsolatot tart, és közremúködik a nemzeti etalonoknak idônként esedékes összehasonlításában. A szervezet múködésével kapcsolatos költségeket a résztvevố államok közösen viselik.

A francia kormány 1882-ben platina-irídium ötvözetból 30 méterrudat és 40 kilogrammhengert készíttetett, amelyek hitelesítését a CIPM végezte el. A CGPM elsố ülését 1889 ószére hívták össze Párizsba, melyen azon etalonok közül, amelyek legjobban megegyeztek a levéltári ósetalonokkal, egyet nemzetközi méterprototípusnak (nemzetközi méternek), egy másikat pedig nemzetközi kilogramm-prototípusnak (nemzetközi kilogrammnak) (5. ábra) minősített.

Azóta ez a két etalon testesítette meg a két alapmértéket, a tömeg mértékegységét még napjainkban is ez képviseli (illetve képviselte 2019. május 19-ig!). A francia nemzetgyúlés által 1799. december 10-én a méter és a kilogramm hiteles megtestesítésének nyilvánított, a francia levéltárban őrzött két alapmérték (Mètre et Kilogramme des Archives), a platinából készített párizsi ôsetalonok 1799-1889 között, tehát 90 évig szolgáltak nemzetközi méter- és kilogrammetalonként. Komoly tudományos teljesítménynek tekinthető, hogy olyan

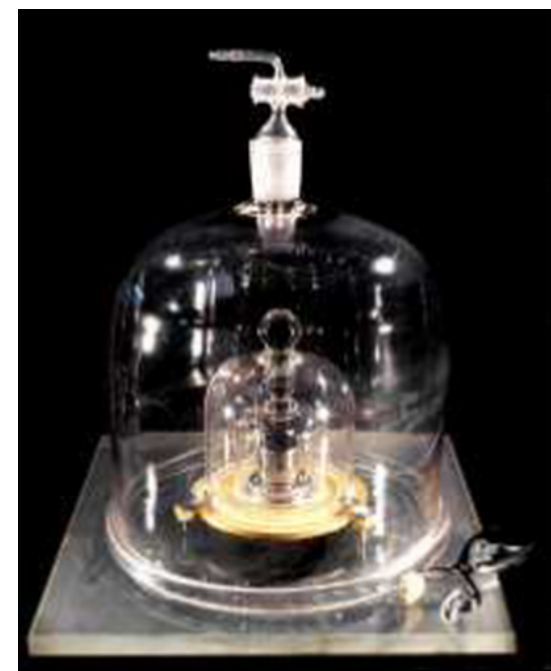

5. ábra. A nemzetközi kilogramm prototípusa három harang alakú üvegbúra alatt állandó hômérsékleten és légnyomáson

etalonokat alkottak a francia forradalom idején, amelyeket 90 év elteltével is alapul vehettek. Emlékeztetünk arra, hogy Kruspér István és Szily Kálmán a Nagy Károly-féle etalonokat 1870 áprilisában, Párizsban ezekkel hasonlította össze.

A többi etalont (a 29 méterrudat és a 39 kilogrammhengert) külön-külön gondosan összehasonlították a nemzetközi méterprototípussal és a nemzetközi kilogramm-prototípussal, megállapították az azoktól való eltéréseket, és azután 1889. szeptember 24-én sorsolással kiosztották azokat a méteregyezményt

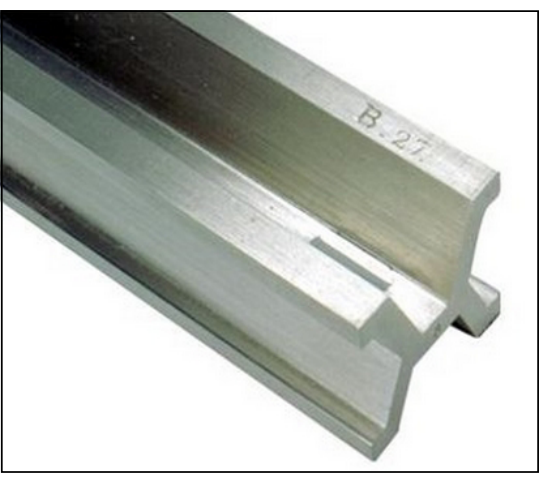

6. ábra. Az USA-nak jutott, X alakú méteretalon részletének látképe

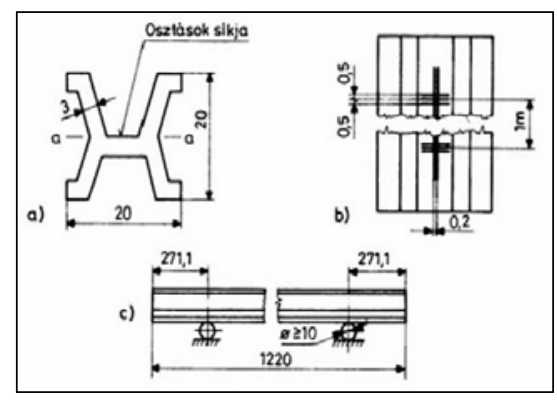

7. ábra. A nemzetközi méter etalonjának metszete és felülnézete 
aláiró (és igénylő) országok között (6. és 7. ábra). Ekkor jutott hazánk birtokába a 14. sorszámú méter-és a 16. sorszámú kilogrammetalon (8. ábra). Az 1891. évi VI. törvénycikk pedig intézkedett arról, hogy a Nagy Kátoly-féle etalonok helyett az 1889-ben megszerzett méterés kilogrammetalon tekintendô törvényes alapmértékeknek Magyarországon. (A Nagy Károly által vásárolt eredeti méteretalon az elsố világháború idején elveszett.)

A méteregyezményhez 1875 óta még 40 ország csatlakozott, így a tagországok száma jelenleg 58, ezen kívül 41 ország társult tagsággal rendelkezik. Így a méterrendszert a világ legtöbb állama már bevezette.

Az 1875-ben létesített nemzetközi méteregyezmény szervezetei eredeti hármas tagozódásban ma is fennállnak és múködnek. A Nemzetközi Súly-és Mértékügyi Hivatal (BIPM) múködésének helyszíne Párizs egyik elôvárosában (Sévres) létrehozott Pavillon de Breteuil (9. ábra).

Nemzetközi státuszú intézmény, és ezért területen kívüliséget élvez, a méteregyezmény tagállamai tartják fenn. (A BIPM éves költségvetése 2019ben 11,980 millió euró (EUR), amelyhez Magyarország mint tagállam 56306 euróval járul hozzá (Presskit 2018).) A BIPM feladata a mérések világméretû egységességének biztosítása. Felelős a fontosabb fizikai mennyiségek

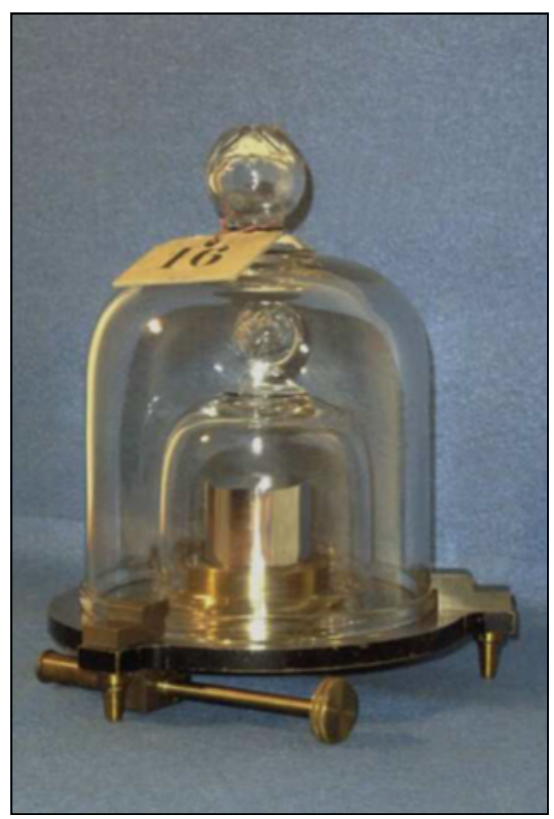

8. ábra. Magyarországnak jutott, 16. sorszámú kilogrammetalon etalonjainak létrehozásáért és fenntartásáért, a nemzeti és nemzetközi etalonok összehasonlításainak szervezéséért, a megfelelő méréstechnikák és az e tevékenységében alkalmazott fizikai állandók meghatározásának koordinálásáért. Tevékenysége alapvetően mérésügyi laboratóriumi munkákra támaszkodik. Feladatai közé tartozik még az is, hogy az idő (egyezményes koordinált világidő, UTC) mérését nagy pontossággal fenntartsa, és a nemzetközi közösség számára rendelkezésre bocsássa. A „BIPM Time Department” jelenleg az IAG egyik nemzetközi szolgálata (Ádám 2006, Drewes-Ádám 2016). A BIPM jelmondata, melyet a nemzetközi etalonokra felvéstek: À tous les temps, à tous les peuples („minden időkre - minden népnek"). A jelvényében (10. ábra)

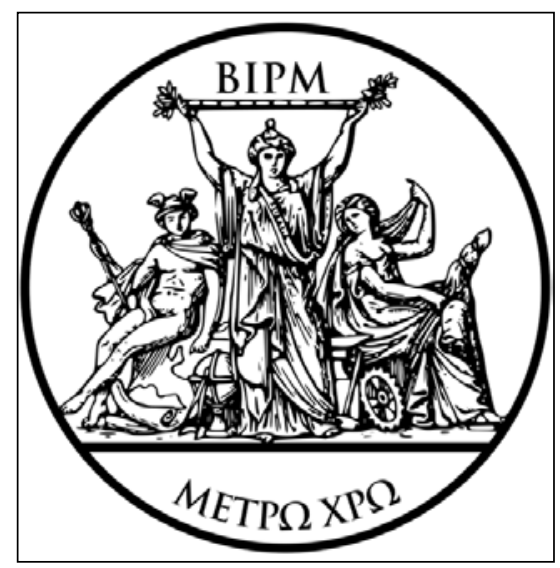

10. ábra. A Nemzetközi Súly-és Mértékügyi Hivatal (BIPM) logója (a BIPM hozzájárulásával) található görög kifejezés magyarra fordítva: „használd a mértéket”.

A BIPM tevékenységét a Nemzetközi Súly-és Mértékügyi Bizottság (CIPM) kizárólagos hatáskörrel felügyeli, melynek korábban 12, jelenleg 18 állandó tagja van. Üléseit évente tartja. Legutóbbiak közül a 105. ülését 2016. október 26-28. között, a 106. ülését 2017. október 16-20. között, a 107. ülését 2018. június 19-21. között, a soron következô legutóbbi, 108. ülését pedig 2019. március 20-21. között tartotta Párizsban. A CIPM munkájában korábban igen tekintélyes volt a magyar részvétel. Magyarországról a CIPM tagja volt Kruspér István 18791894 között 15 évig, Bodola Lajos 1894-1929 között 35 éven keresztül (11. ábra) és Honti Péter 1968-1981 között 13 éven át. Ezen túlmenôen Bodola Lajos professzor 1923-1927 között a CIPM titkári (mai szóhasználattal fótitkári), Honti Péter pedig 1976-1979 között alelnöki feladatokat látott el.

A CIPM az Általános Súly- és Mértékügyi Értekezlet (CGPM, gyakran Nemzetközi Súly- és Mértékügyi Konferencia néven említik) fennhatósága alatt tevékenykedik. A CGPM általában négyévenként tartja üléseit, amelynek résztvevôi a méteregyezmény tagállamainak küldöttjei (12. ábra).

Feladata a nemzetközi mértékegységek fenntartása és a mérésügy

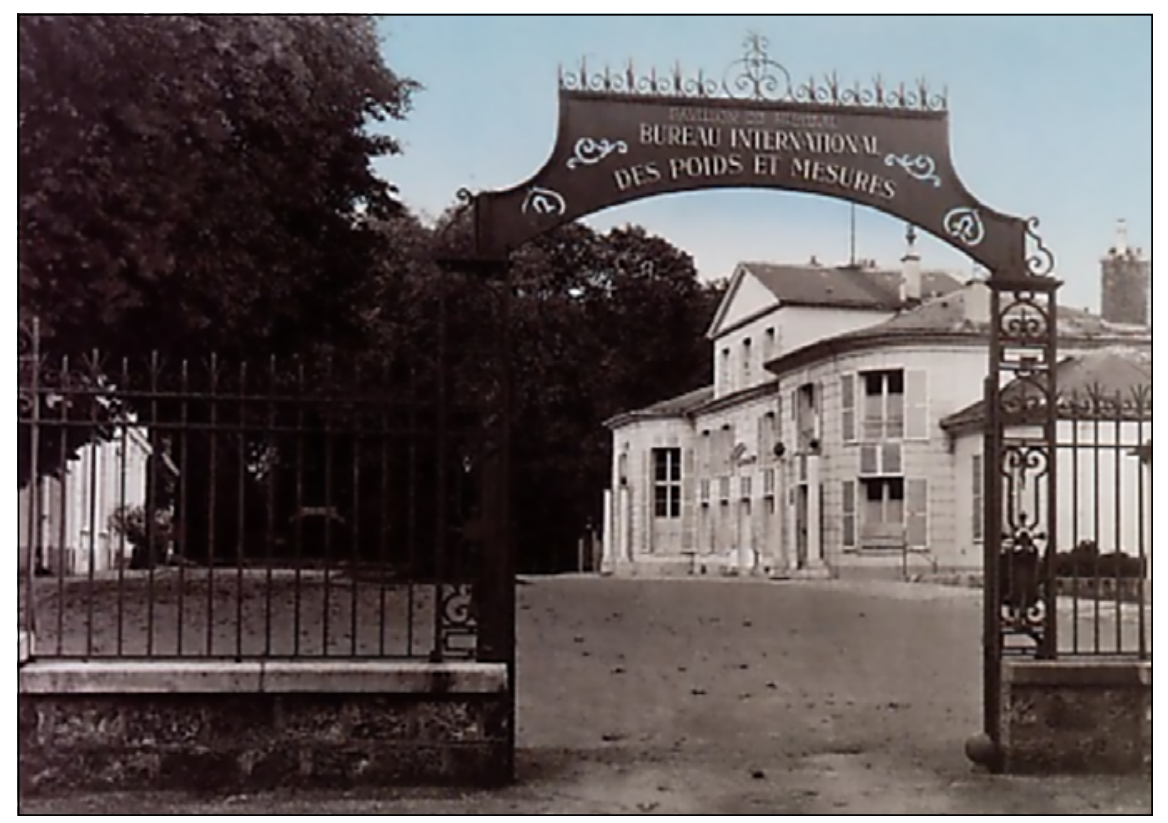

9. ábra. A Nemzetközi Súly-és Mértékügyi Hivatal (BIPM) székhelye Párizs Sévres elôvárosában(a BIPM hozzájárulásával) 


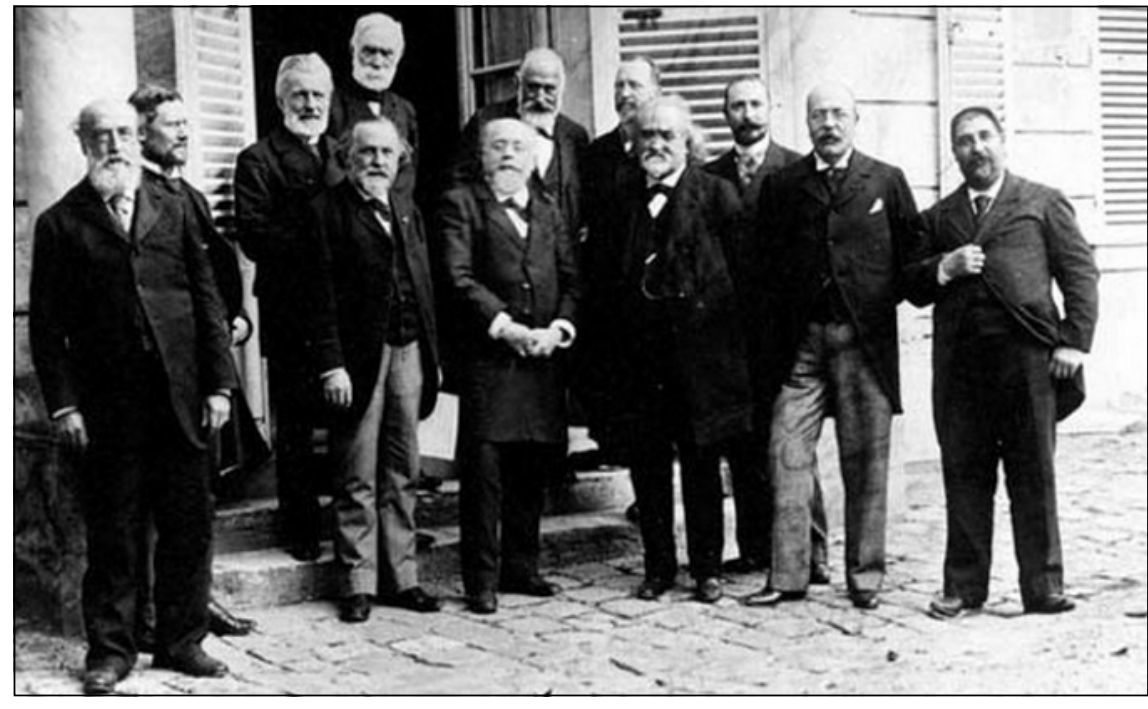

11. ábra. A Nemzetközi Súly-és Mértékügyi Bizottság (CIPM)

10. ülésén (Párizs, 1894. szeptember) részt vett tagok (12 fö) csoportképe. Jobbról a harmadik Bodola Lajos professzor (a BIPM hozzájárulásával)

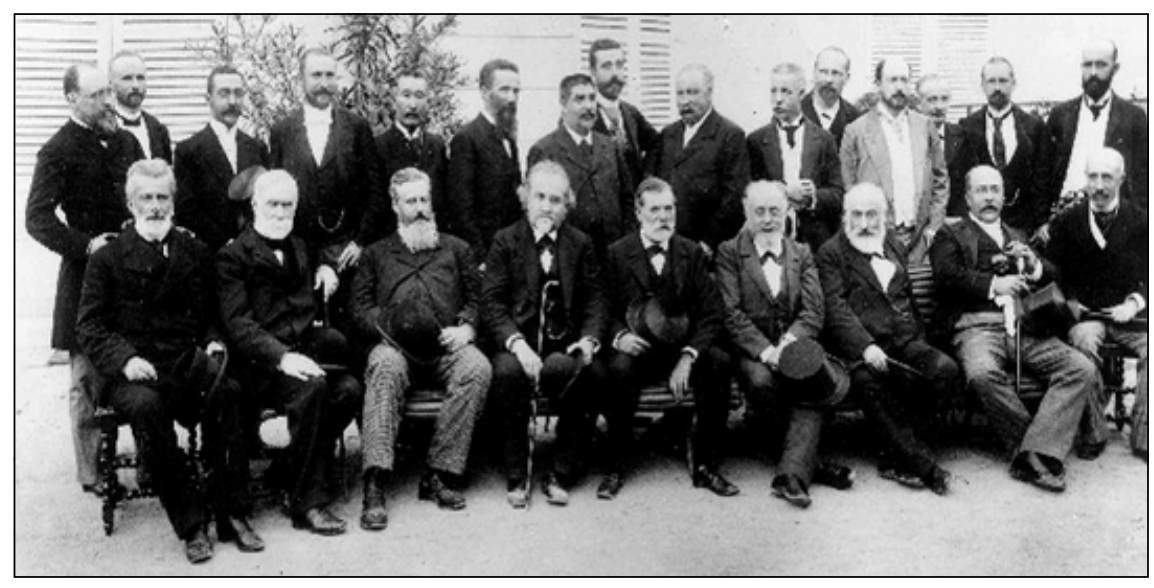

12. ábra. A Nemzetközi Súly-és Mértékügyi Konferencia (CGPM)

2. ülésén (Párizs, 1895. szeptember 4-14. között) részt vett delegátusok csoportképe. A hátsó, álló sorban balról a negyedik Bodola Lajos professzor (a BIPM hozzájárulásával)

nemzetközi feladatainak koordinálása. Jóváhagyja a fizikai alapállandók értékének meghatározását, és dönt a BIPM szervezetét és fejlesztését érintố kérdésekben, ellátja a hivatal munkájának felügyeletét. A CGPM 1889-ben tartott elsố konferenciájának feladata volt a méter- és a kilogrammetalon ellenôrzött másolatainak kiosztása a méteregyezmény tagországainak. 1960-ban pedig létrehozta a mértékegységek nemzetközi rendszerét, röviden az SI-t (Système International d'Unités), amelynek jelenleg is a továbbfejlesztésén dolgozik.

I. táblázat

\begin{tabular}{|l|l|l|l|}
\hline \multicolumn{5}{|c|}{ SI alapegységek } \\
\hline mértékegység neve & \multicolumn{1}{|c|}{ jele } & \multicolumn{1}{c|}{ mennyiség neve } & mennyiség jele \\
\hline méter & $\mathrm{m}$ & hossz & I (kis L) \\
\hline kilogramm & $\mathrm{kg}$ & tömeg & $\mathrm{m}$ \\
\hline másodperc & $\mathrm{s}$ & idô & $\mathrm{t}$ \\
\hline amper & $\mathrm{A}$ & elektromos áramerôsség & $\mathrm{I}$ (nagy i) \\
\hline kelvin & K & abszolút hômérséklet & T \\
\hline mól & mol & anyagmennyiség & $\mathrm{n}$ \\
\hline kandela & cd & fényerôsség & Iv \\
\hline
\end{tabular}

A CGPM legutóbbi, 26. általános értekezletét 2018. november 13-16. között tartották, helyszíne pedig a híres Palais des Congrès de Versailles volt. (Az előző, 25. konferenciát 2014. november 18-20. között rendezték meg Párizsban.)

\section{A mértékegységek nemzetközi rendszere}

\subsection{Az SI egységes} mértékrendszer bevezetése

A jelenleg használt SI egységes mértékrendszert a 11. CGPM fogadta el 1960-ban, amely hét kiválasztott mértékegységen (I. táblázat), illetve a 10 hatványain alapul. A hét SI-alapegység mindegyike dimenziófüggetlen a többitôl (13. ábra). A mértékegységek rendszerét az alapegységek, a kiegészítő egységek és a velük leírható származtatott egységek alkotják.

A geodézia területén három SI-alapegység alapvetô fontosságú: a méter, a kilogramm és a másodperc. A jelenleg érvényes meghatározásuk a következô.

A méter a hosszúság mértékegysége, jele az m, nagyságát a fénynek vákuumban mért sebessége mint természeti állandó alapján állapították meg, amely pontosan 299792 458, és mértékegysége a $\mathrm{m} / \mathrm{s}$. Ennek megfelelốn a méter a fény által a légüres térben (vákuumban) a másodperc 1/299 792 458-ad része alatt megtett út hossza.

A másodperc az alapállapotú cézium-133 atom két hiperfinom energiaszintje közötti átmenetnek

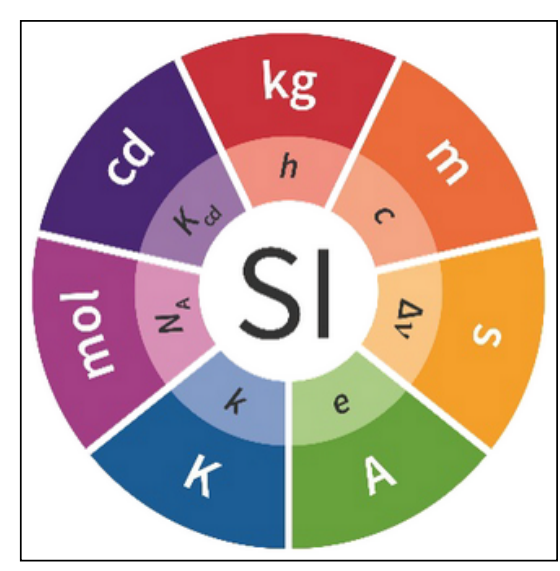

13. ábra. A hét SI alapmértékegység jelének és az alapmérték meghatározásához alapul szolgáló természeti állandó jelölésének kördiagramm-ábrázolása 
II. táblázat

\begin{tabular}{|c|c|c|c|}
\hline \multicolumn{4}{|c|}{ SI-elôtagok (prefixumok) } \\
\hline \multirow[b]{2}{*}{ Elôtag } & \multirow[b]{2}{*}{ Jele } & \multicolumn{2}{|c|}{ Szorzó } \\
\hline & & $\begin{array}{c}\text { hatvány- } \\
\text { nyal }\end{array}$ & számnévvel \\
\hline yotta- & $\mathrm{Y}$ & $10^{24}$ & kvadrillió \\
\hline zetta- & $\mathrm{Z}$ & $10^{21}$ & trilliárd \\
\hline exa- & $\mathrm{E}$ & $10^{18}$ & trillió \\
\hline peta- & $\mathrm{P}$ & $10^{15}$ & billiárd \\
\hline tera- & $\mathrm{T}$ & $10^{12}$ & billió \\
\hline giga- & G & $10^{9}$ & milliárd \\
\hline mega- & M & $10^{6}$ & millió \\
\hline kilo- & $\mathrm{k}$ & $10^{3}$ & ezer \\
\hline hekto- & h & $10^{2}$ & száz \\
\hline deka- & $\begin{array}{l}\mathrm{da} \\
(\mathrm{dk})\end{array}$ & $10^{1}$ & tíz \\
\hline- & - & $10^{\circ}$ & egy \\
\hline deci- & d & $10^{-1}$ & tized \\
\hline centi- & c & $10^{-2}$ & század \\
\hline milli- & $\mathrm{m}$ & $10^{-3}$ & ezred \\
\hline mikro- & $\mu$ & $10^{-6}$ & milliomod \\
\hline nano- & $\mathrm{n}$ & $10^{-9}$ & milliárdod \\
\hline piko- & $\mathrm{p}$ & $10^{-12}$ & billiomod \\
\hline femto- & f & $10^{-15}$ & billiárdod \\
\hline atto- & $\mathrm{a}$ & $10^{-18}$ & trilliomod \\
\hline zepto- & $\mathrm{z}$ & $10^{-21}$ & trilliárdod \\
\hline yokto- & $\mathrm{y}$ & $10^{-24}$ & kvadrilliomod \\
\hline
\end{tabular}

megfelelô sugárzás 9192631770 periódusának idôtartama.

A kilogramm annak a platina-iridium hengernek a tömege, amelyet a BIPM nemzetközi tömeg-alapmérték gyanánt öriz Sévres-ben 2019. május 19-ig.

A mértékegységek gyakran túl kicsinek vagy túl nagynak bizonyulnak, ezért ilyenkor célszerú a mértékegység neve elé illesztett elôtétszó (ún. prefixum) segítségével a többszörösüket, illetve törtrészüket képezni. Ezért a mértékegységek többszörösét vagy tört részét összetett szóval jelöljük. A szóösszetételek előtagját (ún. prefixét), rövidítését és értelmét mutatja a II. táblázat.

A táblázatban foglaltakat a CGPM konferenciáin a tudomány és a mérésügy fejlődésének függvényében fokozatosan alakították ki. Ezek a könnyebb áttekinthetôség érdekében a nagyon nagy illetve a nagyon kicsi mennyiségek rövid leírására szolgálnak, amelyek a tíz hárommal osztható kitevőjű hatványainak rövidítésére használatosak.
III. táblázat

\begin{tabular}{|l|l|l|}
\hline \multicolumn{3}{|c|}{ tervezett SI-elótagok (prefixumok) } \\
\hline Elötag & Jele & Szorzó \\
\hline yototta & Ya & $10^{48}$ \\
\hline zetotta & $\mathrm{Za}$ & $10^{45}$ \\
\hline exotta & $\mathrm{Ea}$ & $10^{42}$ \\
\hline petotta & $\mathrm{Pa}$ & $10^{39}$ \\
\hline terotta & $\mathrm{Ta}$ & $10^{36}$ \\
\hline gigotta & $\mathrm{Ga}$ & $10^{33}$ \\
\hline megotta & $\mathrm{Ma}$ & $10^{30}$ \\
\hline kilotta & $\mathrm{Ka}$ & $10^{27}$ \\
\hline milocto & $\mathrm{mo}$ & $10^{-27}$ \\
\hline micocto & $\mathrm{mo}$ & $10^{-30}$ \\
\hline nanocto & no & $10^{-33}$ \\
\hline picocto & po & $10^{-36}$ \\
\hline femocto & fo & $10^{-39}$ \\
\hline attocto & ao & $10^{-42}$ \\
\hline zepocto & zo & $10^{-45}$ \\
\hline yocotto & yo & $10^{-48}$ \\
\hline
\end{tabular}

Csak néhány olyan elôtag van, amely nem hárommal osztható hatványkitevôjû. Megjegyezzük, hogy a mértékegységek többszöröseinek és törtrészeinek neve van Swindentôl származik (Regốczi 1959). Az elóbbieket görög, az utóbbiakat pedig latin elótagok segítségével alkotta meg. Jelenleg is ezt a gyakorlatot követik. Az SI keretében a mennyiségeknek csak tíz a +24 . és a -24. hatványai szerint kifejezett nagyságrendjére vonatkozó elnevezés van érvényben, de már ismert a tíznek a +48. és a -48. közötti, hárommal osztható kitevôjû hatványainak elnevezése is (III. táblázat).

\subsection{A mértékegységek} nemzetközi rendszerének fenntartása és továbbfejlesztése A mértékegység elvileg szabadon megválasztható, de célszerú oly módon, hogy segítségükkel a mindennapi élet tapasztalatai minél egyszerúbben kifejezhetôk legyenek. A mértékegységeket lehetóleg természeti állandókra vagy jól (elvileg bárki által) visszaállítható (ún. reprodukálható) jelenségekre kell alapítani, és a lehetô legnagyobb körben egyezményesen elfogadtatni. A mértékegységet korábban etalon bevezetésével rögzítették. (Az etalon valamely fizikai mennyiség mértékegységét visszaállítható (reprodukálható) módon megtestesítố mérốeszköz.)

Fontos követelmény, hogy a mértékegység fogalmi meghatározása (definíciója) által biztosított pontosságnak el kell érnie, vagy legalábbis meg kell közelítenie az adott menynyiség mérésénél technikailag elérhetô legnagyobb (szélsô) pontosságot. További fontos szempont még az, hogy az egységet idôtálló módon lehessen rögzíteni. A tudomány fejlődése szempontjából ez a kedvezó, mivel ez könnyíti meg a tudományos eredmények átadását az utókornak (pl. a stádium nagysága nem rekonstruálható egyértelmúen).

A CGPM 24. konferenciáján (Párizs, 2011. október 16-22.) jelentôs döntéseket hoztak az SI nemzetközi mértékegységrendszer jövôjével kapcsolatban. A mértékegységeket általános fizikai állandókkal határozzák meg (definiálják). Rögzítették az I. táblázatban szereplő hét alapegységhez kapcsolódó általános természeti állandó értékét, amelyeket a CGPM 26. konferenciáján (Párizs, Versailles, 2018. november 13-16.) pontosítottak, és 2019. május 20-án (a Metrológia Világnapján) léptek érvénybe (IV. táblázat).

IV. táblázat

\begin{tabular}{|l|l|l|}
\hline \multicolumn{3}{|c|}{ IV.táblázat } \\
\hline \multicolumn{1}{|c|}{ A hét SI-alapegységhez kapcsolódó általános természeti állandó értéke } \\
\hline mértékegység neve & \multicolumn{1}{|c|}{ fizikai állandó neve } & \multicolumn{1}{c|}{ számértéke } \\
\hline méter & a fény sebessége & $\mathrm{c}=299792458 \mathrm{~m} / \mathrm{s}$ \\
\hline kilogramm & Planck-állandó & $\mathrm{h}=6,62607015 \times 10^{-34} \mathrm{Js}$ \\
\hline másodperc & $\begin{array}{l}\text { a cézium-133 által kibocsátott } \\
\text { fény frekvenciája }\end{array}$ & $\mathrm{v}=9192631770 \mathrm{~Hz}$ \\
\hline amper & az elemi töltés nagysága & $\mathrm{e}=1,602176634 \times 10^{-19} \mathrm{C}$ \\
\hline kelvin & Boltzman-állandó & $\mathrm{k}=1,380649 \cdot 10^{-23} \mathrm{~J} / \mathrm{K}$ \\
\hline mól & Avogadró állandó & $\mathrm{N}_{\mathrm{A}}=6,02214076 \times 10^{23} \mathrm{~mol}^{-1}$ \\
\hline kandela & $\begin{array}{l}\text { a spektrális fényhasznosítás } \\
\text { legnagyobb értéke }\end{array}$ & $\mathrm{K}_{\mathrm{cd}}=6831 \mathrm{~m} / \mathrm{W}$ \\
\hline
\end{tabular}


A mérési eljárások pontosabbá válása és egyéb megfontolások miatt az SI néhány alapegységének meghatározása (definíciója) többször is változott, de a mértékegységek gyakorlatilag ugyanakkorák maradtak.

\subsubsection{A méter különbözô fogalmi meghatározásai}

A hosszúság (távolság) az egyik legalapvetôbb fizikai mennyiség, amelynek szerepe a térbeli tájékozódásban meghatározó. Kezdetben a hosszúság alapegységei (mértékegységei) általában az emberi testrészekhez (hüvelyk, láb, könyök stb.), illetve az emberi test egyéb méreteihez (lépés, öl, arasz stb.) kapcsolódtak. Segítségükkel a mindennapi élet tapasztalatai hosszú ideig kifejezhetôk voltak. Azonban a sokféle mértékegység használata egyre több nehézséget okozott, fóleg a kereskedelemben (az egyes alapegységek közötti átváltás miatt), és lényegében nehéz az egységet idôtálló módon rögzíteni. Ezért már Ch. Huygens (1629-1695) a XVII. században felvetette, hogy az alapegységeket ne az emberi test méreteiből, hanem természeti állandókból vezessék le. Ố azt javasolta, hogy a hosszúság egysége a másodpercinga hossza (kb. 0,995 $\mathrm{m}$ ) legyen. Ez a meghatározás szóba is került a francia forradalom idején létesített méterbizottságban is, de elvetették (a másodpercinga hossza ugyanis függ a földfelszíni nehézségi térerôsség [g] értékétől, amely viszont pontról pontra változik).

A hosszúság mértékegységére, a méterre a tudomány és a mérésügy fejlôdésével eddig három fogalmi meghatározást adtak, amelyeket az V. táblázatban foglaltunk össze. Megadtuk az egyes meghatározások relatív hibáját is (Kruspér 1871, Szabó 2002).

Egyre több oldalról merült fel az az igény, hogy a méter fogalmát a BIPMben ôrzött platina-irídium rúdon kijelölt távolságnál maradandóbban, szabatosabban és bármikor előállítható módon határozzák meg. Már az 1880as évek végétôl kutatásokat végeztek arra vonatkozólag, hogy a méter hosszát egy bizonyos fény hullámhosszúsága segítségével fejezzék ki. Ehhez alapul vették azt a tényt, hogy a modern spektroszkópia lehetôvé tette a fény hullámhosszának nagy pontosságú megmérését. Ezzel elhárították azt a veszélyt, hogy az ôsméter (illetve a nemzetközi méter) esetleges megsemmisülése esetén a méter csak csökkent pontossággal állítható vissza. Így 1960-ban született meg a nemzetközi megegyezés a 11. CGPM keretében a méter alapegység V. táblázatban feltüntetett második fogalmi meghatározása vonatkozásában, amely szerint a méter a 86-os tömegszámú kriptonatom két meghatározott energiaszintje közötti átmenetnek $\left(2 \mathrm{p}_{10}-5 \mathrm{~d}_{5}\right)$ megfeleló sugárzás légüres térbeli (vákuumbeli) hullámhosszának 1650 763,73-szorosa („optikai méter”). Fontos körülmény még az, hogy az új meghatározás megadásának relatív hibája $10^{-6}$-ról $5 \times 10^{-9}$ értékre (a pontosság több mint két nagyságrenddel) nôtt.

Az idôközben lefolyt vizsgálatok azt mutatták, hogy egyrészt a kripton sugárzásának stabilitása nem megfelelő, másrészt a modern optika és a lézerfizika területén az 1970-es években jelentôs eredmények születtek. Ebben kiemelkedố szerepe volt Bay Zoltánnak (14. ábra) is, a magyar származású fizikusnak. Ố már 1965-ben

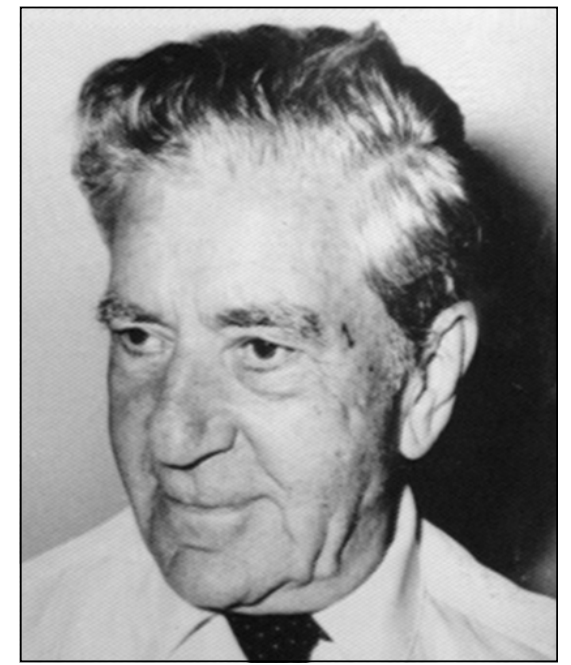

14. ábra. Bay Zoltán akadémikus arcképe

javasolta azt, hogy a távolságegységet, a métert alapozzák a pontosabban mérhetô idôegységre és a fénysebességre. Szakirodalmi kutatásokat végzett a fénysebesség állandóságára vonatkozóan. Kimutatták, hogy a fény terjedési sebessége (299 792458 m/s) légüres térben állandó és független a fényforrástól, a fény erôsségétôl, frekvenciájától, irányától és a mérô személyétől. Ezért a távolság jellemzésére azt az idôt használhatjuk, amennyi alatt a fény a távolságot befutja (Staar 2015).

Az elméleti és kísérleti érvek mind alátámasztják azt, hogy a légüres térbeli (vákuumbeli) fénysebesség a fizika egyik legfontosabb általános (univerzális) állandója. További fontos szempont, hogy a fénysebesség meghatározásának megbízhatósága legalább $10^{-15}$-es határig megegyezik az időegység pontosságával. Ezért született meg 1983-ban a 17. CGPM keretében a méter jelenleg is érvényes (az V. táblázatban feltüntetett) harmadik meghatározása. E szerint a méter annak az útnak a hossza, melyet a fény légüres

V. táblázat

\begin{tabular}{|c|l|l|l|l|}
\hline \multicolumn{5}{|c|}{ A méter különbözó fogalmi meghatározásai (definíciói) } \\
\hline S elnevezés & érvényessége & \multicolumn{1}{|c|}{ fogalmi meghatározás } & $\begin{array}{c}\text { relatív } \\
\text { pontossága }\end{array}$ \\
\hline 1 & $\begin{array}{l}\text { a Föld méretén és alakján alapuló méter } \\
\text { a) „levéltári méter” vagy „ósméter” (platinából) } \\
\text { b) „nemzetközi méter” (platina-íridium ötvözetból) }\end{array}$ & $\begin{array}{l}1799-1889 \\
1889-1960\end{array}$ & $\begin{array}{l}\text { egy méter egyenló a Föld meridián kvadrán- } \\
\text { sának tízmilliomod részével }\end{array}$ & $10^{-6}$ \\
\hline 2 & $\begin{array}{l}\text { az atomi sugárzás hullámhosszán alapuló méter } \\
\text { („optikai méter”) }\end{array}$ & $1960-1983$ & $\begin{array}{l}\text { a méter a 86-os tömegszámú kripton atom } \\
\text { 2p10 és 5 d5 energiaszintjei közötti átmenet- } \\
\text { nek megfelelố, vákuumban terjedó sugárzás } \\
\text { hullámhosszúságának 1 650 763,73-szorosa }\end{array}$ & $5 \times 10^{-9}$ \\
\hline 3 & $\begin{array}{l}\text { a fénysebességen alapuló méter } \\
\text { („fényreszabott méter”) }\end{array}$ & $\begin{array}{l}\text { a méter a fény által a vákuumban a másod- } \\
\text { perc 1/299 792 458-ad része alatt megtett út } \\
\text { hossza }\end{array}$ & 1983 óta \\
\hline
\end{tabular}


térben 1/299 792458 másodperc alatt tesz meg („fényre szabott méter”).

A meghatározás jelentôsége az, hogy az idô mérésén alapul, amelynek mérési pontosságát céziumatom-órákkal $10^{-15}$ fölé lehet emelni. A meghatározás könnyen használható, és lényeges elônye, hogy a méter olyan pontos lesz, mint a másodperc. Ezt a meghatározást (definíciót) véglegesnek tekintik, a métert várhatóan nem kell többé újra meghatározni.

A fénysebesség állandóságának elve a metrológia és a geodézia számára azzal a nagyon fontos következménynyel jár, hogy a távolságmérésben az idômérési módszereket használhatjuk fel. Ezen az elven múködik a globális navigációs múholdrendszerek (GNSS: GPS, Glonassz, Galileo, Beidou stb.), a múholdakra és a Holdra történó lézeres távolságmérés, a VLBI stb. (Ádám et al. 2004, Biró et al. 2013).

Megjegyezzük, hogy a méter eredeti meghatározása tulajdonképpen ma is a párizsi meridián (délkör) hoszszán alapszik. A fogalmi meghatározás (definíció) helyébe csak a mérési eljárások fejlôdése miatt kerültek egyre pontosabb, új meghatározások (definíciók). Az ôsméter és a nemzetközi méter, továbbá az ôskilogramm múzeumi tárgyak lettek (a Louvre Múzeumban ôrzik ôket, és várhatóan még ez évben a nemzetközi kilogramm is odakerül melléjük). A magyar hivatalos (1889-ben kapott 14. sorszámú) méteretalon a Magyar Kereskedelmi Engedélyezési Hivatal (illetve mai jogutód szervezete, a Budapest Fôváros Kormányhivatala (BFKH) Metrológiai és Múszaki Felügyeleti Fôosztálya) tulajdonában van, és a Magyar Nemzeti Múzeum Állandó Történeti Kiállításán látható (várhatóan ez év második felétôl a 16. sorszámú kilogrammetalonnal együtt).

\subsubsection{Az idô alapegységének meghatározásai}

Az idő a hosszúság (távolság) mellett a fizikának másik alapvetô mennyisége, mely a geodéziában is alapvetó szerepet játszik. Mérésére önmagával azonos módon, tetszólegesen sokszor lejátszódó események egymásutánja (ún. periódusos folyamat) használható. Az időfogalom kialakulásában is döntô szerepet játszó ilyen periódusos folyamat célszerúen a nappalok és éjszakák váltakozása. A csillagászat fejlôdésével megjelentek a napnál rövidebb és hosszabb idôegységek (így pl. a kb. 30 napos holdhónap is). A 360 napos év alapján külön számrendszerek (12-es és 60-as) alakultak ki, melyeket ma már csak az időmérésben használunk. A tudomány fejlôdése magával hozta végül a rövid (perc, másodperc) idôegységek kialakulását.

Az idó elsó, tudományosan meghatározott egysége a másodperc volt, amelyet 1820-ban egy francia tudóscsoport (Szabó 2002) javaslatára a közepes szoláris nap 1/86400ad részeként határoztak meg. Ez a fogalmi meghatározás (definíció) 1960-ig volt érvényben (VI. táblázat), mivel a Föld tengely körüli forgásának részletes vizsgálata során kimutatták, hogy forgási sebessége a Föld belsejében és a felületén a különbözô természeti jelenségek következtében létrejövő tömegátrendezôdések miatt ingadozik, valamint kis mértékben folyamatosan lassul (mintegy $2,5 \times 10^{-4} \mathrm{~s}$ /év mértékben). A Földnek a Naphoz viszonyított tengelyforgása nem egyenletes.

A VI. táblázatban megadtuk az idô alapegysége, a másodperc meghatározásainak (megvalósításainak, realizációjuknak) relatív hibáját a külföldi szakirodalom alapján (Boucher-Willis 2017: 243. oldal).
A Föld Nap körüli keringési (efemerisz) idejét a külsố természeti tényezôk sokkal kevésbé befolyásolják. Ezért 1960-ban a 11. CGPM keretében a másodperc efemeriszidôhöz kötött meghatározását hagyták jóvá. Ennek értelmében a másodperc az 1900. január 1-jei 00 óra efemeriszidôhöz tartozó tropikus év 1/31 556925,9747 -ed része (VI. táblázat). Ez a fogalmi meghatározás rövid ideig, mindössze 7 évig volt érvényben.

A tudományos igények és ismeretek növekedése szükségessé tette a másodperc fogalmának az eddigieknél nagyobb pontosságú és a csillagászatiföldtudományi jelenségektől független meghatározását. Ugyanis a spektroszkópia és az atomfizika rohamos fejlôdése az 1960-as években lehetôvé tette a másodperc sokkal pontosabb és idôtállóbb meghatározását. Ennek alapját az alkotja, hogy az atomok, molekulák meghatározott energiaszintjei közötti átmenetekhez tartozó sugárzások rezgésszáma a külsố körülményektôl és a kozmológiai idố múlásától is független. Az ún. atomórák ilyen karakterisztikus rezgéseknek a számlálásával múködnek. Úgy döntöttek, hogy egy másodperc az az idô legyen, amely alatt a céziumóra egy meghatározott számú rezgést végez. Az elôzőok alapján 1967 ben, a 13. CGPM keretében fogadták el a másodperc ma is érvényes, harmadik meghatározását (VI. táblázat), amely szerint a másodperc az alapállapotú cézium-133 atom két hiperfinom energiaszintje közötti átmenetnek megfelelô sugárzás 9192631770 periódusának idôtartama. Ezt a meghatározást úgy választották meg, hogy a másodperc és az efemeriszmásodperc hoszszúsága azonos legyen.

A másodperc harmadik meghatározása a céziummal múködô atomórát teszi elsốdleges forrásnak az idô- és

\begin{tabular}{|c|c|c|c|c|}
\hline \multicolumn{5}{|c|}{ A másodperc különbözố fogalmi meghatározásai (definíciói) } \\
\hline $\mathbf{S}$ & elnevezés & érvényessége & fogalmi meghatározás & $\begin{array}{c}\text { relatív } \\
\text { pontossága }\end{array}$ \\
\hline 1 & a Föld forgásán alapuló másodperc & $1820-1960$ & a másodperc a szoláris középnap 1/86400-ad része & $2 \times 10^{-8}$ \\
\hline 2 & $\begin{array}{l}\text { a Föld Nap körüli keringési (efemerisz) } \\
\text { idején alapuló másodperc }\end{array}$ & $1960-1967$ & $\begin{array}{l}\text { a másodperc az } 1900 \text {. év január } 1.0 \text { óra efemerisz idő- } \\
\text { höz tartozó trópikus év } 1 / 31556925,9747 \text {-ed része }\end{array}$ & $2 \times 10^{-9}$ \\
\hline 3 & az atomi sugárzáson alapuló másodperc & 1967 óta & $\begin{array}{l}\text { a másodperc az alapállapotú cézium -133 atom két } \\
\text { hiperfinom energiaszintje közötti átmenetnek megfe- } \\
\text { lelô sugárzás } 9192631770 \text { periódusának idôtartama }\end{array}$ & $0,3 \times 10^{-15}$ \\
\hline
\end{tabular}


frekvenciaméréseknél. További fontos körülmény, hogy a másik fizikai alapmennyiség, a méter ma már a másodperc meghatározására támaszkodik.

Az idômérés területén nagyarányú tudományos-technikai fejlôdés és fejlesztés tapasztalható. Az IUGG/IAG legutóbbi általános közgyúlésén (Prága, 2015. június 22. - július 2., Ádám 2015) a geodéziatudomány területén mutattak be figyelemre méltó fejlôdési lehetőségeket olyan optikai atomórák alkalmazásával, amelyek relatív pontossága már $10^{-18}$. Francia kutatók olyan ún. optikairács-órákat alkottak, amelyek 300 millió évente késnek egyetlen másodpercet. Olyan ún. ionórán is dolgoznak, amely néhány milliárd év alatt mutat egy másodperces késést.

Az idô egyre pontosabb mérésére a távközlés és az ûrkutatás, különösen a múholdas helymeghatározás és navigáció (GNSS) területén mutatkozik egyre nagyobb igény, a megkívánt gyakorlati eredmények pontosságának fokozása érdekében. Ezért várható, hogy legközelebb a másodperc új fogalmi meghatározásával fognak foglalkozni, és a soron következố valamelyik CGPMülésen várható majd döntés ezzel kapcsolatban.

Megjegyezzük, hogy a másodperchez elôtagok, ún. prefixumok csak a törtrészeinek kifejezésére használatosak: pl. $0,001 \mathrm{~s}=10^{-3} \mathrm{~s}=1 \mathrm{~ms}, 10^{-9} \mathrm{~s}=1 \mathrm{~ns}$ vagy pl. $10^{-18}=1$ as.

\subsubsection{A kilogramm új meghatározása}

A tömeg a fizika (mechanika) és a geodézia harmadik legfontosabb mennyisége. 2019. május 19-ig a kilogramm volt az egyetlen olyan alapegység, amely még nem valamely alapvetó fizikai állandón alapult. Mivel a kilogrammetalon veszít a tömegéból (ismeretlen okok miatt), ezért a tömeg alapegységét is egy természetes állandóból kívánják származtatni a CGPM 24. konferenciájának értelmében. Ezért nemzetközi szinten négy módszer is versengett az utóbbi két évtizedben azért, hogy vonatkoztatási (referencia)mérésként szolgáljon a kilogramm számára. Ezek közül kettônek: a Planckállandón vagy az Avogadro-állandón alapuló meghatározásnak volt esélye. Az érintett kutatócsoportok (amerikai és német csoportok) 2017 júliusáig nyújthatták be elôterjesztésüket, és a CGPM 26. konferenciája döntött a kérdésben 2018. november 16-án (Press kit 2018).

A döntés értelmében a tömeg alapegységének (kilogramm) új fogalmi meghatározása (definíciója) 2019. május 20-án (a Metrológia

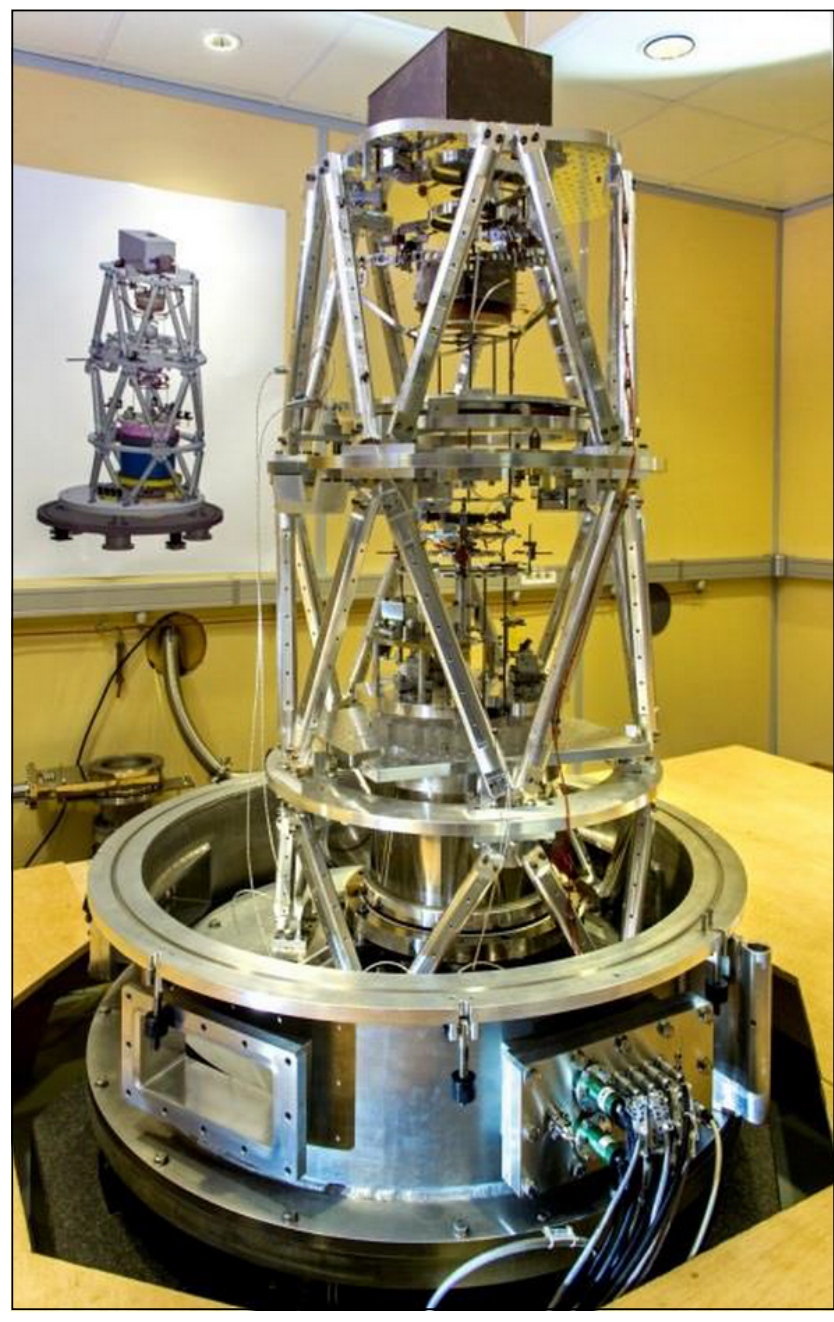

15. ábra. A kilogramm-alapegység számára összehasonlító (referencia) mérésként szolgáló, ún. Kibble-mérleg látképe

Világnapján) lép érvénybe (VII. táblázat). Addig még az elsố fogalmi meghatározás (definíció) van érvényben, amely szerint a kilogramm akkora tömeg, amely megegyezik a BIPM páncéltermében, állandó hơmérsékleten és páratartalmon, három harang alakú üvegbúra alatt

\begin{tabular}{|c|c|c|c|c|}
\hline \multicolumn{5}{|c|}{ A kilogramm különbözố fogalmi meghatározásai (definíciói) } \\
\hline $\mathbf{S}$ & elnevezés & érvényessége & fogalmi meghatározás & $\begin{array}{c}\text { relatív } \\
\text { pontossága }\end{array}$ \\
\hline \multirow[t]{3}{*}{1} & & & $\begin{array}{l}\text { A kilogramm egy dm }{ }^{3} \text { víz tömege a legnagyobb súrúségú állapotban } 3,9840^{\circ} \mathrm{C} \text {-on } \\
\text { és normál légköri nyomáson: }\end{array}$ & \\
\hline & $\begin{array}{l}\text { „levéltári kilo- } \\
\text { gramm" }\end{array}$ & $1799-1889$ & $\begin{array}{l}\text { a) a kilogramm annak a platinából készült testnek a tömege, melyet a francia } \\
\text { levéltárban ôriztek }\end{array}$ & $10^{-5}$ \\
\hline & $\begin{array}{l}\text { „nemzetközi } \\
\text { kilogramm" }\end{array}$ & $1889-2019$ & $\begin{array}{l}\text { b) a kilogramm annak a platina-íridium ötvözetbôl készült } 39,17 \mathrm{~mm} \text { átmérôjû́ } \\
\text { és magasságú hengernek a tömege, melyet a BIPM nemzetközi tömegalapmérték } \\
\text { gyanánt ôriz Sévresben }\end{array}$ & $?$ \\
\hline 2 & $\begin{array}{l}\text { a Planck-féle } \\
\text { állandón alapu- } \\
\text { ló kilogramm }\end{array}$ & 2019 óta & $\begin{array}{l}\text { A kilogramm az a tömeg, amely pontosan } 2 \times 10^{-7} \mathrm{~m} / \mathrm{s}^{2} \text { gyorsulással mozogna, ha } \\
\text { akkora erố hatna rá, mint az elhanyagolható keresztmetszetű, egymástól } 1 \text { méter } \\
\text { távolságban haladó végtelen hosszú párhuzamos vezetôpár egy méteres szaka- } \\
\text { szán, ha a vezetôkön keresztül pontosan } 6,24150962915265 \times 10^{18} \text { elemi } \\
\text { töltés másodpercenkénti áram folyna. }\end{array}$ & $1 \times 10^{-8}$ \\
\hline
\end{tabular}


tartott kilogrammetalon (2. és 5. ábra) tömegével.

Az új (a második) meghatározás a kvantumfizikában ismert Planck-féle állandón alapszik, amelynek jelenleg elfogadott számértékét a IV. táblázatban tüntettük fel. Az amerikai szabványügyi hivatal szakemberei hosszú évek kísérletei után látták elérkezettnek az idốt arra, hogy a kilogrammot a Planck-állandó segítségével határozzák meg újra. A Planck-állandó jelentôsége abban van, hogy kapcsolatot teremt a fotonok energiája és frekvenciája között, és az Einstein-féle híres energia-tömeg ekvivalencia-egyenlet alapján megfeleltethető a tömegnek. A definícióhoz nagyon pontosan megmérték a Planck-állandót (IV. táblázat), amelyhez egy speciális mérleget, az ún. Kibble-mérleget (15. ábra) (korábbi vizsgálatokban a Watt-mérleget) használták. Lényegében kétkarú mérlegrôl van szó, amelynek egyik karjára egy ismert súlyt helyeznek el, a másik karját pedig mérhetố árammal múködtetett elektromágnessel egyensúlyozzák ki. Ily módon a kutatók 3,6 × 10-6 os relatív pontossággal mérték meg a Planck-állandót.

Megjegyezzük, hogy ha az Avogadroállandót vették volna alapul, akkor ezzel két alapegységet (tömeg és a mól) határoztak volna meg. Ezzel kapcsolatban a braunschweigi metrológiai intézetben a német kutatók egy $10 \mathrm{~cm}$ átmérójú szilícium-28 gömböt készítettek. Az $1 \mathrm{~kg}$ tömegú szilíciumgömbben található atomok száma lett volna a kilogramm új fogalmi meghatározása (definíciója). Mivel az Avogadro-szám a természetes fizikai alapállandók közé tartozik, és értékét nagy pontossággal ismerjük, ezért ennek alapján pontosan meg tudják mondani, hány darab atom van egy kilogramm szilícium-28 gömbben.

A magyar hivatalos (1889-ben kapott 16. sorszámú) kilogrammetalont utoljára 2007-ben, illetve 2017-ben hitelesítették Párizsban.

\section{4. Összefoglalás}

AXVIII.századvégén Franciaországban kezdődött el olyan tudományos alapú mértékegységrendszer kidolgozása, melynek alapegységei (mértékegységei) a Föld egyes geometriai és fizikai (mechanikai) jellemzôihez kapcsolódtak. A folyamat lényegében 1790. április 17-én Charles Maurice de Talleyraud-Périgond-nak (Autun püspökének) a Francia Nemzetgyúlésben elhangzott elôadásával vette kezdetét, amelyben ismertette tervét a 10-es számrendszert (decimális rendszert) használó és a természeten (a Földön) alapuló új mértékrendszer megalkotásáról. Franciaország vezetô matematikusai, fizikusai, csillagászai, vegyészei és filozófusai (pl. Laplace, Legendre, Delambre, Mechani stb.) aktív közremúködésével a francia forradalom idôszakában (kellôs közepén) az 1790-es évek folyamán született meg a mértékrendszer.

A hosszúság (távolság) alapegységének ekkor választották a métert, amelyet a párizsi meridián az Északisark és az Egyenlítő közé esô ívhoszszának (ún. meridiánkvadránsának) tízmilliomod részeként határoztak meg. Ehhez végezték a nevezetes méterfokmérést, amelyet 1792-1798 között hajtottak végre, és az eredményeket 1799-ben tették közzé (220 évvel ezelőtt).

Ezzel egyidejûleg a tömeg mértékegységének az $1 \mathrm{dm}^{3}, 4{ }^{\circ} \mathrm{C}$-os desztillált víz tömegét választották, és ez az egység lett a kilogramm. Ezáltal a tömeg mértékegysége a köbdeciméter közvetítésével a méterhez, illetve ezen keresztül szintén a Föld méreteihez kapcsolódik.

Az idố mérése szintén a Földhöz, közelebbrôl ennek mozgásához (forgásához és keringéséhez) kapcsolódott. Alapja a Nap egymás utáni két delelése között eltelt idő, az egy nap. A napot 24 egyenlô részre osztották, és az így kapott részeket nevezték órának. Ehhez hasonlóan az órákat 60 percre, a perceket 60 másodpercre osztották, tehát 1 nap $=24$ óra $=1440$ perc = 86400 másodperc. A fizikában az idő mértékegysége az így értelmezhetô másodperc lett.

A mértékegységek megalkotóit végig az az elgondolás vezette, hogy a hosszúság és a tömeg, valamint a geodéziában ezek mellett alapvetô fontosságú idố mértékegysége olyan legyen, amely a természet (a Földünk) nyújtotta méretekbôl és jelenségekbôl bármikor visszaállítható. A mérési pontosság fokozatos növekedése odavezetett, hogy az alapegységeket ma már természetes fizikai állandók alapul vételével határozzák meg (definiálják). A CGPM legutóbbi (26.) konferenciáján (Versailles, 2018) lényegében a hét alapmértékegységhez kapcsolódó természeti/technikai állandók értékét rögzítették, így mérési bizonytalanságuk nincs, és ezek segítségével valósítják meg az alapmértékegységeket, ellentétben a korábbi gyakorlattal, amelynek során elsőként létrehozták a mértékegységek etalonjait és azokkal mérték meg a természeti állandókat.

Magyarország már az 1800-as évek elején szakembereinek francia kapcsolatai alapján tájékozódott a témakörben és Nagy Károly csillagász (az MTA tagja) szorgalmazta az egységes 10-es számrendszerú (decimális) mértékegységrendszer mielóbbi hazai bevezetését. Az elsố méter- és kilogrammetalont saját költségén ô szerezte meg 1844-ben. A méterrendszer bevezetése tárgykörében az elsô hivatalos lépést 152 évvel ezelốtt, 1867 júliusában tették meg.

Magyarország nemcsak a méteregyezmény (Convention du Mètre) elsố elfogadói között szerepel, hanem a Múegyetem két elismert professzorával, nevezetesen Kruspér István és Szily Kálmán akadémikusokkal annak elôkészítésében is részt vett. Kruspér István az egyik fontos albizottság elnökeként múködött, és tagja volt a CIPM akkor 12 tagból álló szervezetének 1879-1894 között. Ôt követte Bodola Lajos múegyetemi professzor (szintén az MTA tagja) 1894-1929 között, aki a CIPM titkári (mai szóhasználattal élve a fótitkári) tisztségét is betöltötte.

A méter jelenlegi fogalmi meghatározását (definícióját) a CGPM 1983. évi 17. konferenciája fogadta el Bay Zoltán javaslatára, így ebben Bay Zoltán tevékenysége meghatározó. Már 1965-ben javasolta, hogy a métert a pontosabban mérhetố idôegységre és a fénysebességre alapozzák. Meggyốzôdése volt, hogy a fénysebességre alapított egyesített téridôrendszer lesz a jövô mérési 
rendszere. A távolságot ugyanis órával lehet mérni (lényegében ez történik pl. a GNSS és a lézeres távolságmérés esetén), mert a tér és idố nem függetlenül léteznek. A fénysebesség meghatározó alapállandó, nem ismerünk semmi más mennyiséget a természetben, amelynek állandósága ekkora viszonylagos pontosságú (10${ }^{17}$ ). A fénysebesség SI egységekben mért, 1983-ban elfogadott számértéke (c = $299792458 \mathrm{~m} / \mathrm{s}$ ) rögzített szám (nem változik akkor sem, ha a fény sebességét idôvel pontosabban ismerhetjük!).

Végül megjegyezzük, hogy a nemzetközi mértékegységrendszer folyamatos felülvizsgálatát és változtatásait a globális kereskedelem és a múszaki/ tudományos innovációk támogatása érdekében végzik, és hozzák meg a szükséges döntéseket, határozatokat. Így a méteregyezmény keretében 1875-ben létrehozott szervezet múködésére hármas tagozódásban (BIPM, CGPM és CIPM) továbbra is kiemelten szükség van.

\section{Köszönetnyilvánítás}

A szerző a tanulmányában foglaltakat különbözố kiméretben a következó rendezvényeken mutatta be:

a) Biró Péter akadémikus 85. születésnapja alkalmából a Magyar Tudományos Akadémián (MTA) 2015. december 4-én szervezett ünnepi tudományos előadóülésen („A felsőgeodézia tárgykörébe tartozó szabványok és konvenciók"),

b) az Erdélyi Magyar Múszaki Tudományos Társaság (EMT) XVIII. Földmérố Találkozó (Tusnádfürdô, 2017. május 18-21. között) szakmai programja keretében („Szabványok és konvenciók szerepe a geodéziában"),

c) az MTA Földtudományok Osztályának 2017. szeptember 17-i ülésén („Az egységes mértékrendszer kialakítása és hazai bevezetésének akadémiai vonatkozásai"),

d) a Borsod-Abaúj-Zemplén Megyei Mérnöki Kamara által szervezett „Miskolci Mérnöki Nap” 2017. szeptember 22-i elôadóülésén („Az egységes mértékegységrendszer kialakítása és hazai bevezetése"), e) a BME Általános- és Felsốgeodézia Tanszék és az MFTTT Geodéziai Szakosztálya közös szervezésében a Rédey István Geodéziai Szemináriumán 2017. november 2-án („Az egységes mértékegységrendszer kialakítása és hazai bevezetése"),

f) a Nógrád Megyei Mérnöki Kamara és az MFTTT megyei területi csoportja „XI. Tavaszi Mérnöknap, NÓGRÁD 2019” elnevezésû́ rendezvényén 2019. április 9-én Salgótarjánban szervezett Földmérô Szakmai Napon („Az egységes mértékegységrendszer kialakítása, fenntartása és továbbfejlesztése"). Így az összeállítás szövege tartalmilag fokozatosan alakult ki.

\section{Irodalom}

Ádám J. 2006. Az IAG globális geodéziai meg figyelôrendszere. Geodézia és Kartográfia 58. évf. pp. 6-17.

Ádám J. 2015. IUGG/IAG 26. általános közgyúlése. Geodézia és Kartográfia, 67. évf pp. 4-9.

Ádám J.-Bányai L.-Borza T.-Busics Gy.Kenyeres A.-Krauter A.-Takács B. 2004. Mûholdas helymeghatározás. Mû́egyetemi Kiadó, Budapest.

Angermann, D. 2012. Standards and Conventions for Geodesy. In The Geodesist's Handbook 2012, szerk.: Drewes, H.- Hornik, H.- Ádám J.- Rózsa Sz., Journal of Geodesy, Vol. 86, pp. 961-964. DOI: https://doi. org/10.1007/s00190-012-0584-1

Angermann, D.-Gruber, T.-Gerstl, M.Heinkelmann, R.-Hugentobler, U.-Sánchez, L.-Steigenberger, P. 2016. GGOS Bureau of Products and Standards Inventory of Standards and Conventions used for the Generation of IAG Products. In The Geodesist's Handbook 2016, szerk.: Drewes, H.-Kuglitsch, F-Ádám J.-Rózsa Sz., Journal of Geodesy, Vol. 90, pp. 1095-1156. DOI: https:// doi.org/10.1007/s00190-016-0948-z

Biró P.-Ádám J.-Völgyesi L.-Tóth Gy. 2013. A felsôgeodézia elmélete és gyakorlata. HM Zrínyi Térképészeti és Kommunikációs Szolgáltató Nonprofit Kft., Budapest.

Boucher, C.-Willis, P. 2017. Les références de temps et d'espace (Time and Space references). Editions Hermann, Sciences et arts, 400 pages, ISBN 978-270-5684-18 1, Paris.

Busics Gy. 2016. A középkori magyar templomok méretei és a királyi öl kapcsolata. Geodézia és Kartográfia 68. évf. 1-2. sz. pp. 7-12.

Drewes, H. 2008. Standards and Conventions relevant for Geodesy. In The Geodesist's Handbook 2008, szerk.: Drewes, H.- Hornik, H.- Ádám J. - Rózsa Sz., Journal of Geodesy, Vol. 82, No. 11, pp. 833-835. DOI: https:// doi.org/10.1007/s00190-012-0584-1

Drewes, H.- Ádám J. 2016: The International Association of Geodesy-Historical Overview. In The Geodesist's Handbook 2016, szerk.: Drewes, H. - Kuglitsch, F. Ádám J. - Rózsa Sz., Journal of Geodesy,
Vol. 90, pp. 913-920. DOI 10.1007/ s00190-016-0948-z

Fejes I. - Nagy S. 2008. Mindennapi tér-idônk Magyar Tudomány, 169. évf., 11. sz., pp. 1350-1358.

Homoródi L. 1966. Felsôgeodézia. Tankönyvkiadó, Budapest.

Kruspér I. 1871. A párizsi méter-prototyp az 1870. augusztusi méterértekezleten. Értekezések a math. és term. tud. körébôl, (http://real-eod.mtak.hu/1632/), Pest.

Markó L. - Burucs K. - Balogh M. -Hay, D. 2003. A Magyar Tudományos Akadémia tagjai 1825-2002. MTA Társadalomkutató Központ - Tudománytár, I-III. kötet, Budapest.

Milton, M. J. T. 2018. The redefinition of the base units of the SI: how we achieved it. (https://www.bipm.org/utils/common/pdf/ talks/Milton-MJT-2018-APMP-Revised-SI. pdf)

Oltay K. 1938. Zágoni Bodola Lajos élete és múvei. Geodéziai Közlöny, XIV. évf., 1-4. szám, pp. 1-11.

Oltay K. - Rédey I. 1962. Geodézia. Egyetemi tankönyv (harmadik, átdolgozott kiadás). Tankönyvkiadó, Budapest.

Press kit 2018. 26th General Conference on Weights and Measures (CGPM; Versailles, 13-16 November, 2018) - Towards a historic revision of the International System of Units (SI) (https://www.bipm.org/en/ cgpm-2018).

Regốczi E. 1949. Toise, öl, méter. Az Állami Földmérés Közleményei, I. évf., 4. szám, pp. 123-126.

Regő́czi E. 1959. A mértékegységek. Geodézia és Kartográfia, 11. évf., pp. 126-128.

Regốczi E. 1961. A levéltári métertôl az optikai méterig. Geodézia és Kartográfia, 13. évf., 3. sz., pp. 165-170.

Regốczi E. 1968. Kruspér István emlékezete. Geodézia és Kartográfia, 20. évf., 2. szám, pp. 81-86.

Rédey I. 1966. A geodézia története. (ÉKME Mérnöki Karának egyetemi jegyzete.) Tankönyvkiadó, Budapest.

Staar Gy. 2015. Fényreszabott méter Beszélgetés Bay Zoltánnal. Természet Világa, 146. évf., 2015/II. különszáma, pp 45-48.

Szabó, G. 2002. A fizikai mennyiség fogalma; idô és hosszúság. (titan.physx.u-szeged. hu/ opthome/optics/oktatas/Fiz inf 1/fiz menny.pdf)

Verő J. 1976. Akadémiánk és a méter-rendszer bevezetése. Magyar Tudomány, 1976/2 (http://members.iif.hu/visontay/ponticulus/ rovatok/limes/meter.html).

https://hu.wikipédia.org/wiki/Kilogramm https://hu.wikipédia.org/wiki/Másodperc https://hu.wikipédia.org/wiki/Méter Wikipédia számos ismertetôje.

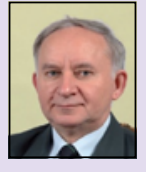

Dr. Ádám József egyetemi tanár az MTA rendes tagja

BME Általános- és Felsőgeodézia Tanszék jadam@epito.bme.hu 